\title{
Expression of Neuronal and Non-Neuronal Markers in the Vomeronasal Organs of One-Humped Camel (Camelus dromedarius) and Egyptian Water Buffalo (Bubalus bubalis)
}

\author{
Expresión de Marcadores Neuronales y No Neuronales en los Órganos \\ Vomeronasales del Camello Jorobado y el Búfalo Egipcio de Agua
}

Mahmoud Abdelghaffar Emam*; Anwar A. El-Shafey"** \& Ahmed A. Kassab***

EMAM, M. A.; EL-SHAFEY, A. A. \& KASSAB, A. A. Expression of neuronal and non-neuronal markers in the vomeronasal organs of one-humped camel (Camelus dromedarius) and Egyptian water buffalo (Bubalus bubalis). Int. J. Morphol., 34(4):1211-1217, 2016.

SUMMARY: Fourteen vomeronasal organs (VNOs) of adult males one-humped camels (Camelus dromedarius) and Egyptian water buffaloes (Bubalus bubalis) $(\mathrm{n}=7 / \mathrm{each})$ were examined immunohistochemically with neuronal markers; synaptophysin (SYP) and glial fibrillary acidic protein (GFAP) to clarify the distribution of the vomeronasal (VN) receptor cells and nerve fibers, in addition to elucidate the existence of non-neuronal elements via S-100 and endothelial nitric oxide synthase (eNOS). In both animals, the VNO was lined medially with VN sensory (olfactory) epithelium and non-sensory (respiratory) epithelium laterally. Immunohistochemically, both animals showed SYP immunolabeling only in the receptor cells of VN sensory epithelium while GFAP labeled the ensheathing cells of the nerve fibers of VNOs. Both S-100 and eNOS labeled non-neuronal elements of the VNO; the supporting cells of sensory epithelium and the VN glands. In view of these observations, we postulate that the VNOs of both animals contain various cells populations that express several neuronal and non-neuronal markers. As well as, SYP and GFAP are suggested as markers for receptor cells and ensheathing cells of nerves of the VNOs respectively. However, no clear differences can be detected in the expressions of neuronal and non-neuronal markers in VNOs of camel and buffalo since they are ruminant species.

KEY WORDS: Vomeronasal organ; Camel; Buffalo; Immunohistochemistry.

\section{INTRODUCTION}

Male individuals of most domestic animals commonly use the flehmen response as an olfactory mechanism for identifying the reproductive state of females of the same species based on transferring pheromones in the female's urine or genitalia into the vomeronasal organ (VNO). VNO is considered as an accessory olfactory system (Witt et al., 2002; Halpern \& Martínez-Marcos, 2003; Karimi et al., 2007). It acts as a chemosensory organ where VN sensory neurons detect chemical signals such as pheromones that evoke sexual behavior (Zufall et al., 2002; Keverne, 2004; Kimoto et al., 2005). Both onehumped camel (Camelus dromedarius) and Egyptian water buffaloes (Bubalus bubalis), as large ruminants, are very important for the Egyptian food security. Males of both animals exhibit different sexual behavioral response during courtship of their females. Considering this, we aimed to describe the functional immunohistochemistry difference between their VNOs.
We examined their VNOs immunohistochemically with neuronal markers; SYP and GFAP to clarify the distribution of VN receptor cells and nerve fibers in the VNOs. In addition, to elucidate the existence of non-neuronal elements, we examined the VNOs with S-100 and eNOS.

SYP is a glycoprotein present in synaptic vesicles in almost all neurons and it is used as an immunohistochemical marker for neuronal tissues (Smith et al., 1993) while, GFAP is a major intermediate filament found in glial cells (Eng $e t$ al., 1985) and it has been expressed in the supporting cells of the olfactory epithelium (Kim et al., 2005). S-100 protein is an acidic calcium-binding protein that has been detected in the olfactory mucosa and VNO (Wang et al., 1994) but, eNOS is an enzyme that produces nitric oxide which is suggested to be involved in olfactory perception (Yamamoto et al., 2003; Endo et al., 2011).

\footnotetext{
* Histology and Cytology Department, Faculty of Veterinary Medicine, Benha University, Benha, Egypt.

** Anatomy and Embryology Department, Faculty of Veterinary Medicine, Benha University, Benha, Egypt.
} 


\section{MATERIAL AND METHOD}

Animals and tissue processing: Heads from 14 apparently healthy, adult males' one-humped camels (Camelus dromedarius) and Egyptian water buffaloes (Bubalus bubalis) (7 heads/each) were obtained from a local slaughterhouse (Toukh, Kalubyia, Egypt) during winter of 2015. The animals were slaughtered according to guidelines of Benha University animal care committee. The heads were dissected to obtain the VNOs as a pair of tubes situated at the base of the nasal septum. Small pieces $(1 / 2 \mathrm{~cm})$ from the mid part of the VNOs were immersed in $10 \%$ neutral buffered formalin, then routinely processed and embedded in paraffin, and cut transversally at $5 \mathrm{~mm}$. Sections were stained with haematoxylin and eosin for general histological structure.

Immunohistochemistry: Sections of $5 \mathrm{~mm}$ thickness were stained by immunohistochemical avidin-biotin method as follows. After rehydration, the sections were incubated for $30 \mathrm{~min}$ in $3 \%$ hydrogen peroxide in methanol then incubated for $30 \mathrm{~min}$ in $1 \%$ normal goat and rabbit serum diluted in PBS. Sections were incubated with the primary antibodies (Table I) for $1 \mathrm{~h}$ at room temperature (RT). Sections were incubated for 30 min at RT with anti-rabbit and anti-goat IgG then with Vectastain ${ }^{\circledR}$ Elite (Vector Laboratories, Burlingame, CA, USA) for the same time. A diaminobenzidine solution was used for the final staining. The specificity of the immunoreaction was detected substituting the primary antibodies with non-immune goat and rabbit IgG (Santa Cruz Biotechnology, CA, USA) to obtain negative control sections. The stained sections were finally captured by light microscope Leica DM3000 LED.

\section{RESULTS}

Histological observation: The VNOs of both one-humped camels and Egyptian water buffaloes had VN lumen and are encapsulated by hyaline cartilage (Figs.1A, B). The VN lumen was lined with respiratory epithelium (non-sensory epithelium) at the lateral convex surface of the lumen while the medial concave surface of the lumen was lined with VN sensory (olfactory) epithelium. The respiratory epithelium consisted of pseudostratified ciliated columnar epithelium with goblet cells (Figs. 1C, D). In the VN sensory epithelium, nuclei of the basal cells were situated at the basal region, while those of the receptor cells were situated at the middle region. In addition, nuclei of the supporting cells were located at the apical region of the epithelium (Fig. 1E, F). Propriasubmucosa consisted of a vascular loose connective tissue which gave cavernous appearance (Fig. 1). Numerous serous and mucous VN glands were found in propria-submucosa, with small secretory ducts ending in the lumen of the organ (Figs. 1C, D).

Immunohistochemical observation: Depending on blind examination by two independent observers, the intensities of immunostaining were scored as negative (-), weak (+), moderate $(++)$ or strong $(+++)$. The expressions of neuronal and non-neuronal markers in the VNOs of both animals were summarized in Table II. The findings showed unclear differences in the expression of one-humped camel and Egyptian water buffalo for neuronal and non-neuronal protein markers.

SYP was restricted only to the VN sensory epithelium. SYP labeled only the receptor cells in the VN sensory epithelium, but did not label the supporting or basal cells. The SYP labeled cells appeared as pear shaped cells (Figs. 2A, B). In both of camel and buffalo, GFAP immunostaining could not be seen in the VN sensory, nonsensory epithelium or glands. GFAP labeled only ensheathing cells of the scattered nerve fibers in lamina propria of VNO (Fig. 2C, D).

S-100 intensely labeled the apical part of supporting cells of the VN sensory epithelium in addition to scattered nerve fibers and $\mathrm{VN}$ glands in lamina propria-submucosa of the VNO (Fig. 3).

Moderate eNOS immunostaining was observed mainly in the free border of the VN sensory epithelium (Figs. 4A, B) while weak eNOS was seen in the VN glands (Figs. $4 C$, D). Immunostainings for SYP, GFAP, S-100, and eNOS were considered positive in comparison to negative control sections as shown in Fig. 5.

Table I. Data of the used antibodies in the present study.

\begin{tabular}{lllll}
\hline \multicolumn{1}{c}{ Antibody } & $\begin{array}{c}\text { Catalogue } \\
\text { number }\end{array}$ & Source & Cross reactivity & Dilution \\
\hline Goat polyclonal anti-SYP & sc-7569 & Santa Cruz Biotech., CA, USA & Equine, bovine, porcine & $1: 200$ \\
Goat polyclonal anti-GFAP & sc-6170 & Santa Cruz Biotech., CA, USA & Equine, canine, bovine & $1: 150$ \\
Rabbit polyclonal anti-eNOS & sc-7849-R & Santa Cruz Biotech., CA, USA & Equine, canine, bovine & $1: 200$ \\
Rabbit polyclonal anti-S100 & ab5589 & Abcam, Cambridge, MA, USA & Cow, pig, dog & $1: 100$ \\
\hline
\end{tabular}



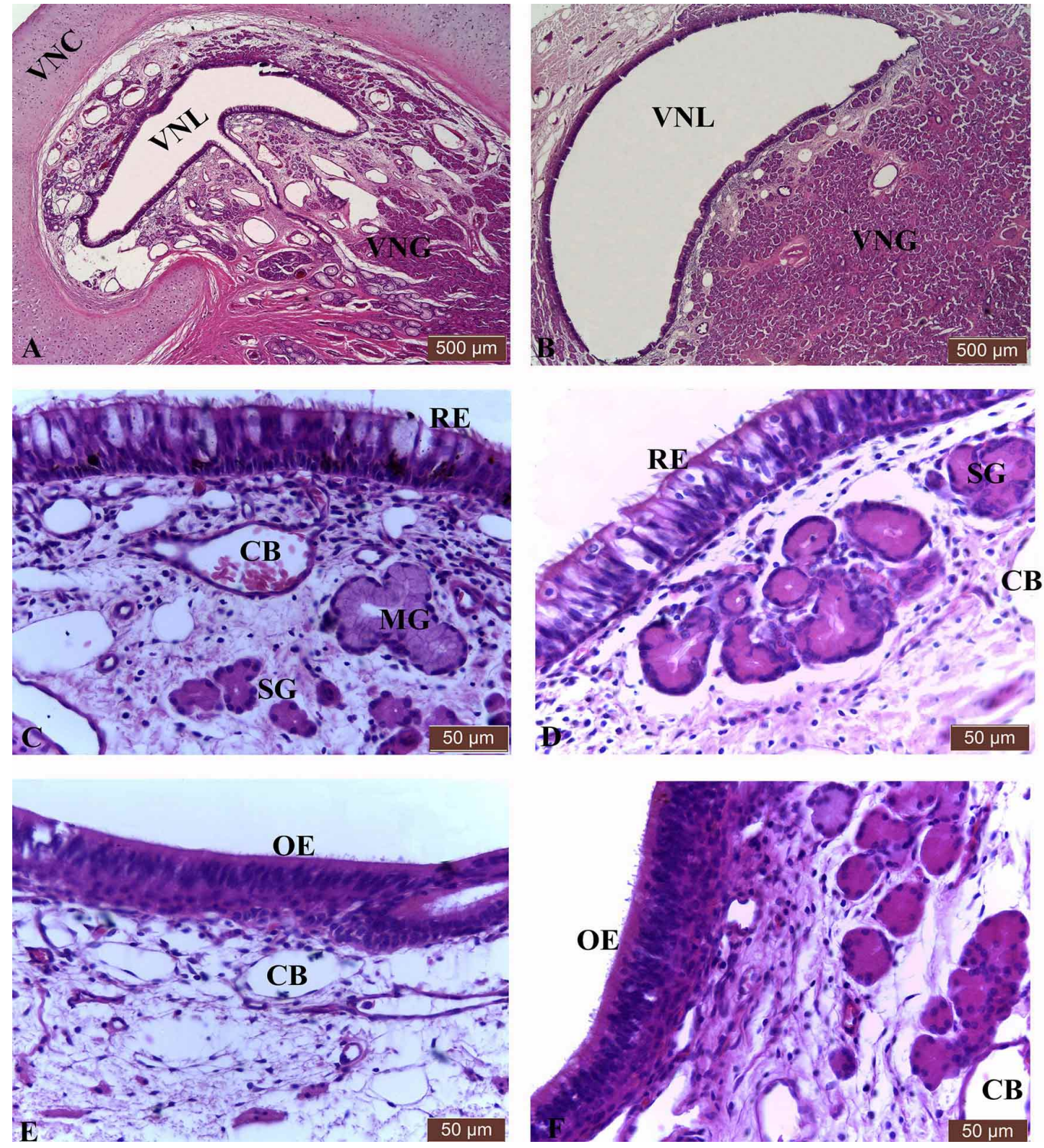

Fig. 1. Transverse sections of the VNO in the camel (Figs. A, C, E) and buffalo (Figs. B, D, F) stained with H\&E. Figs. A and B. General view of VNO of camel and buffalo. VNL, vomeronasal lumen; VNG, vomeronasal gland; VNC, vomeronasal cartilage. Scale bar $=500 \mathrm{~mm}$. Figs. C and D. Respiratory epithelial lining of the VNO of camel and buffalo. RE, respiratory epithelium; MG, mucous gland; SG, serous gland; $\mathrm{CB}$, caves of blood. Scale bar $=50 \mathrm{~mm}$. Figs. E and F. Olfactory epithelial lining of the VNO of both camel and buffalo. OE, olfactory epithelium; CB, caves of blood. Scale bar $=50 \mathrm{~mm}$.

Table II. Summary of immunostaining intensities of neuronal and non-neuronal markers in the VNO of both one-humped camel and Egyptian buffalo.

\begin{tabular}{|c|c|c|c|c|c|}
\hline & \multicolumn{3}{|c|}{ VN sensory epithelium } & \multirow[t]{2}{*}{ VN glands } & \multirow{2}{*}{$\begin{array}{c}\text { VN nerve } \\
\text { fibers }\end{array}$} \\
\hline & Supporting cells & Receptor cells & $\begin{array}{l}\text { Basal } \\
\text { cells }\end{array}$ & & \\
\hline SYP & - & ++ & - & - & - \\
\hline GFAP & - & - & - & - & +++ \\
\hline S-100 & +++ & + & - & +++ & + \\
\hline eNOS & ++ & + & - & + & - \\
\hline
\end{tabular}

-, negative; +, weak immunostaining; ++, moderate immunostaining; +++, strong immunostaining. 


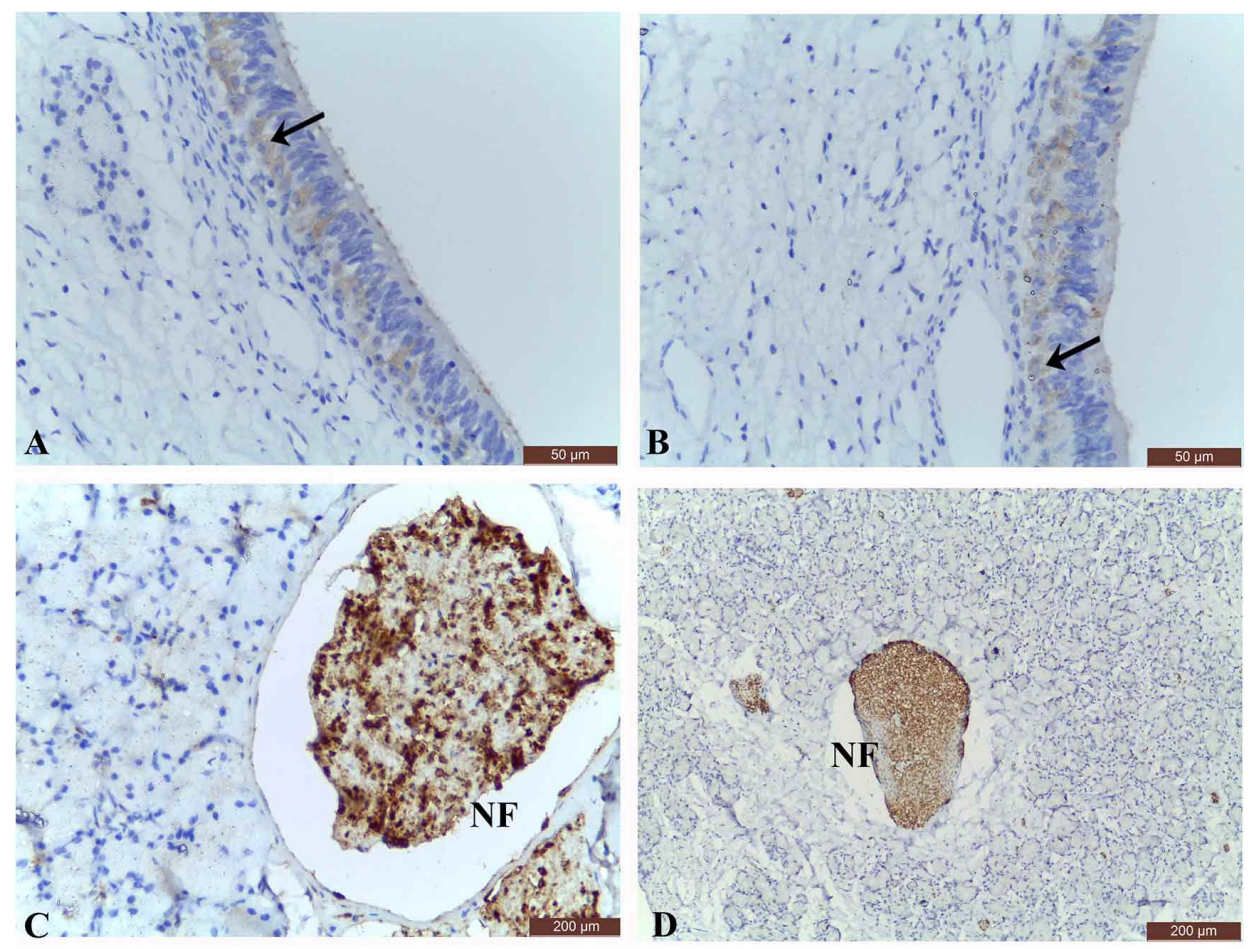

Fig. 2. Immunohistochemical stainings for SYP and GFAP in the VNO of camel (Figs. A, C) and buffalo (Figs. B, D). Figs. A and B. SYP immunostaining in the receptor cells of the VN sensory epithelium (arrow). Scale bar $=50 \mathrm{~mm}$. Figs. C and D. GFAP immunostaining in the ensheathing cells of the nerve fibers (NF) in the lamina propria of VNO. Scale bar $=200 \mathrm{~mm}$.
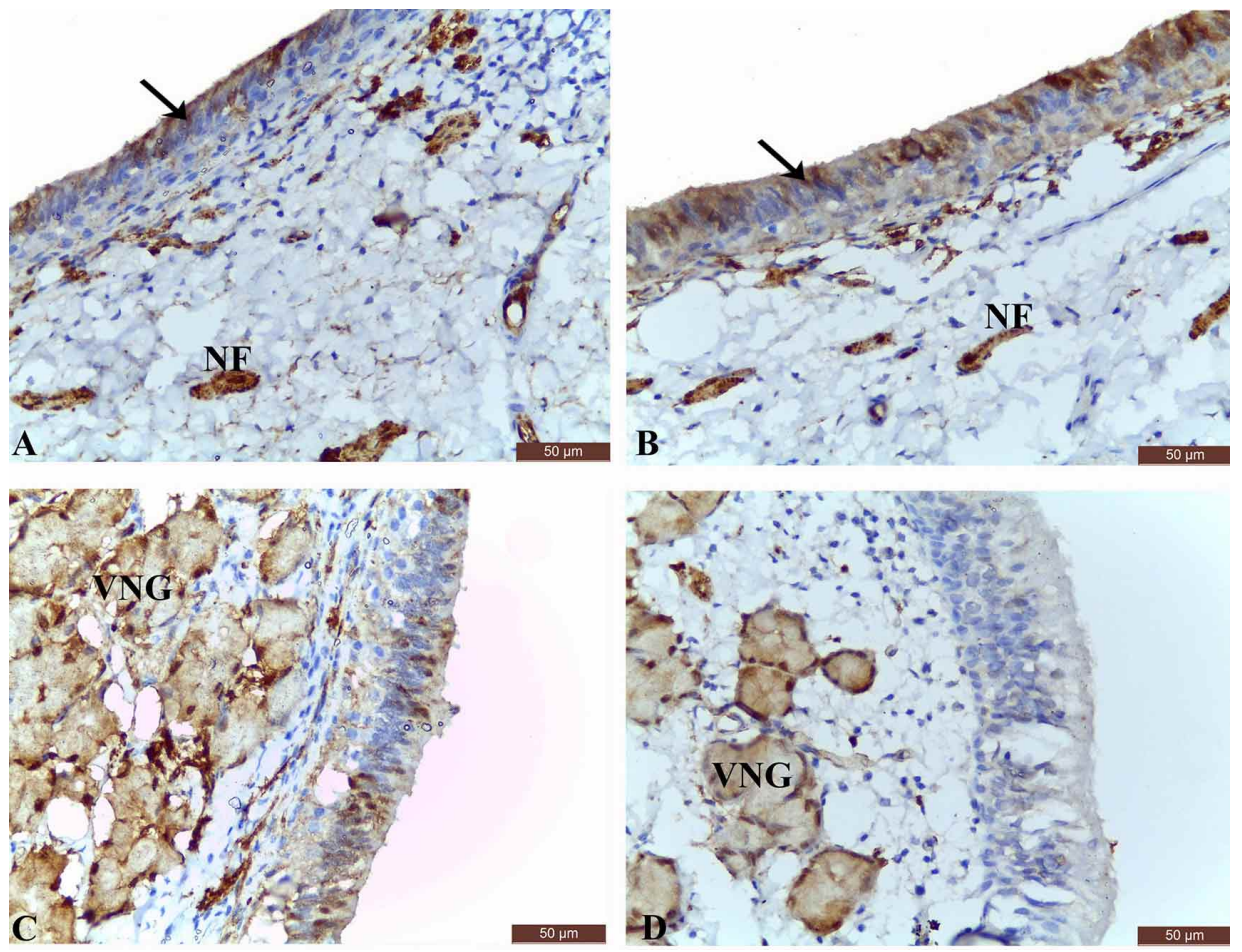

Fig. 3. Immunohistochemical staining for S-100 in the VNO of camel (Figs. A, C) and buffalo (Figs. B, D). Intense immunostaining for S-100 in the apical part of the supporting cells of VN sensory epithelium (arrow), scattered nerve fibers (NF) and VN glands (VNG) in the propriasubmucosa of VNO. Scale bar $=50 \mathrm{~mm}$. 

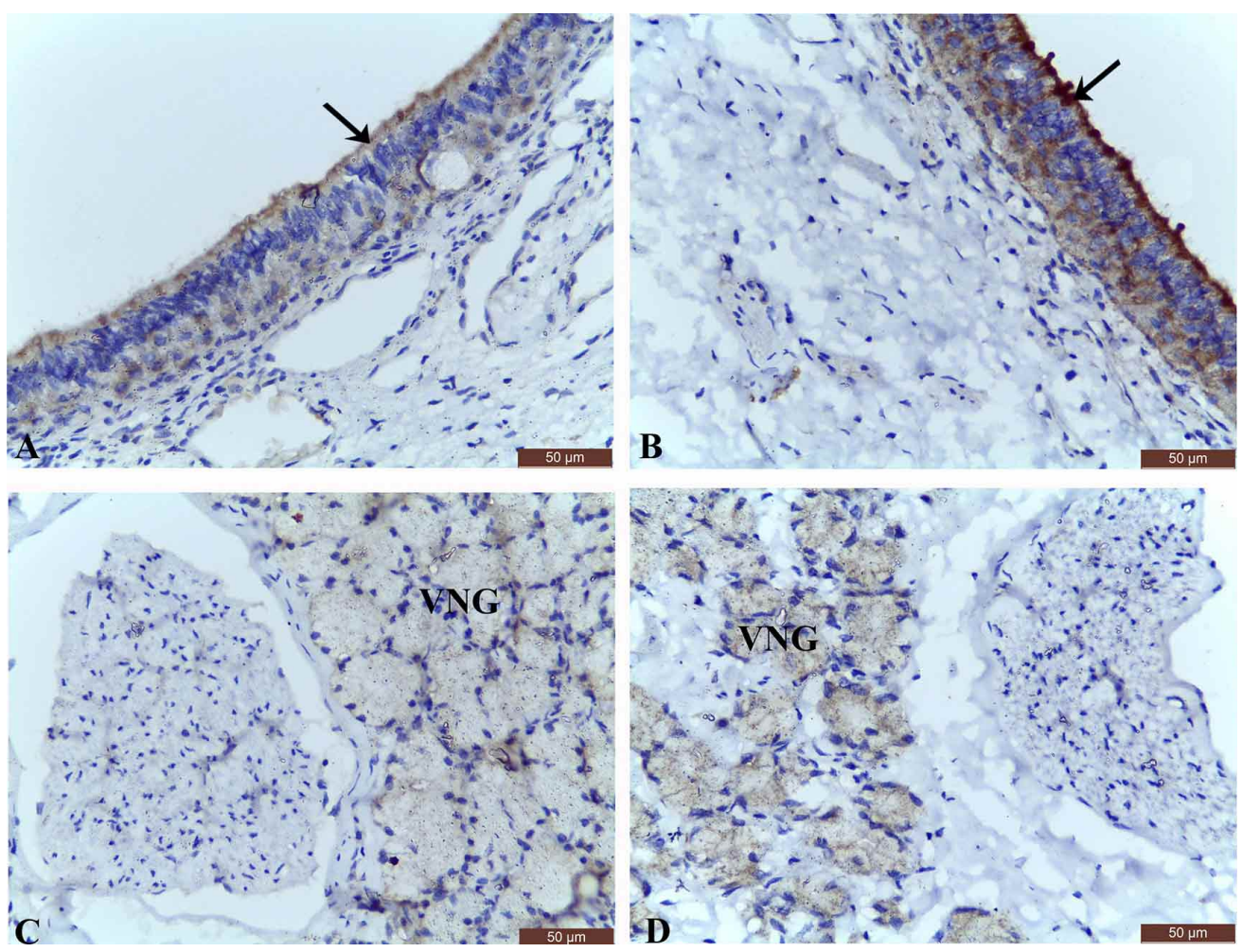

Fig. 4. Immunohistochemical staining for eNOS in the VNO of camel (Figs. A, C) and buffalo (Figs. B, D). Moderate eNOS immunostaining observed in the free border of the VN sensory epithelium (arrow). Weak eNOS immunostaining observed in the vomeronasal glands (VNG). Scale bar $=50 \mathrm{~mm}$.
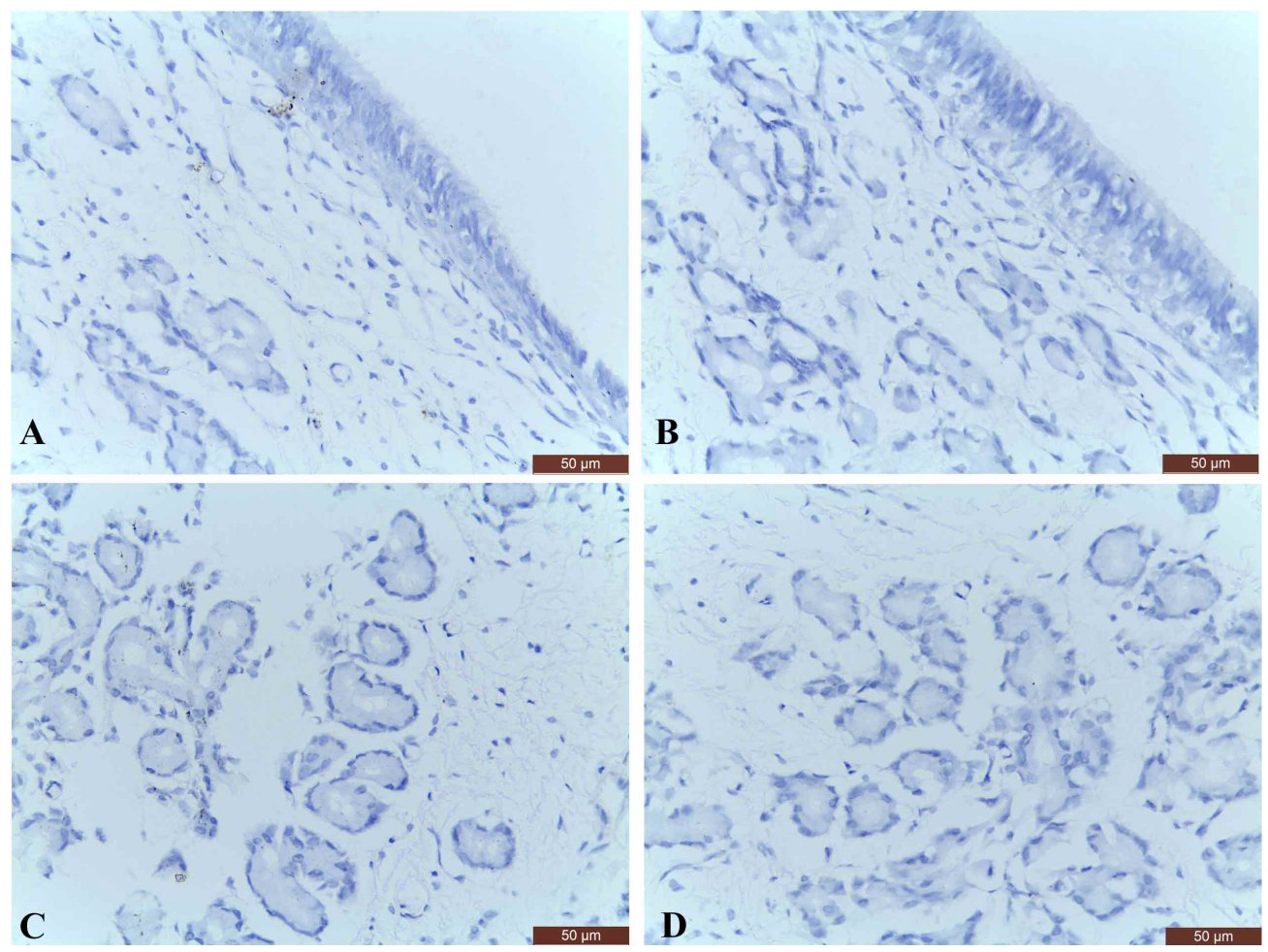

Fig.5. Negative control sections for SYP, GFAP, S-100 and eNOS. Immunohistochemical staining of VNO of camel (Figs. A, C) and buffalo (Figs. B, D) with non-immune IgG as negative control 


\section{DISCUSSION}

Like histological findings of Ibrahim et al. (2015) and Karimi et al. (2014) in camel, Ardalani et al. (2000) and Abbasi (2007) in buffalo, the VNOs of both one-humped camel and Egyptian buffalo in the present study are encapsulated by hyaline cartilage and lined medially with sensory epithelium and laterally with non-sensory epithelium. Propria-submucosa contains numerous VN glands whose secretion is essential for pheromones contacting VNO chemoreceptors (Zufall et al.; Nunez Chichet et al., 2007). Moreover, the vascularity of propriasubmucosa plays important role through the outflow and inflow of blood stream during breeding of the animals aiding in flehmen response (Abass et al., 2012).

Immunohistochemically, it was interesting that the VNOs of both one-humped camel and Egyptian water buffalo showed unclear differences in the expressions of neuronal and non-neuronal markers. Such finding indicates the similarity of functional histology of the VNOs in both animals since they are ruminant species. In both animals, the localization of SYP in receptor cells of the VN sensory epithelium indicates the functional nature of $\mathrm{VN}$ receptors as signal transduction (Eisthen, 1992; Menco et al., 2001). In accordance with the view that GFAP is a classical glial marker such as astrocytes, nerve surrounding cells and satellite cells in ganglia (Kim et al.), our results confirmed the expression of GFAP in the ensheathing cells of VN nerve axons in the propria-submucosa of VNOs of both animals. Contrary to Kim et al., our results did not detect GFAP in the VN epithelium that was in consistence with Witt et al. Such finding does not suggest GFAP as a biomarker for supporting cells in VNOs of camel and buffalo that contradict Rio et al. (2002) and Smithson \& Kawaja (2009) in mice. Therefore, we suggest a species variation in GFAP expression in the $\mathrm{VNO}$ of different animals but its expression in camel and buffalo is still similar. Furthermore, we suggest GFAP as markers for the ensheathing cells of nerve fibers in VNOs of both camel and buffalo.

S-100 was intensely expressed in the supporting cells of VN epithelium in both animals that was similar to findings of Witt et al. Such finding supports Smithson \& Kawaja who considered S-100 as biomarker for olfactory supporting cells. Also, S-100 was intensely expressed in the VN gland that supports Kahn et al. (1983) who detected S-100 in various exocrine glands in the body. Since $\mathrm{S}-100$ is a calcium binding protein, such picture indicates an increase in calcium transport through, or demands within the $\mathrm{VN}$ epithelium and glands so that, S-100 may be involved in the exocytosis of $\mathrm{VN}$ glandular secretion.
eNOS was expressed in the free luminal surface of the VN sensory epithelium in both animals. Such finding was in accordance with Endo et al. as they detected eNOS in the free border of the olfactory epithelium. The expression of eNOS in the VNOs of both camel and buffalo confirms the suggestion of eNOS as a candidate enzyme to produce nitric oxide in the VNO epithelium which is involved in olfactory perception (Yamamoto et al., 2003; Endo et al.).

In conclusion, the VNOs of both one-humped camels and Egyptian water buffaloes contain various cells populations that express several neuronal and non-neuronal markers. Expression of SYP and GFAP in the VNOs indicate the sensory and nervous function of VNOs, while expression of S-100 indicates calcium transportation or demand via VN epithelium and glands, as well as expression of eNOS indicates production of nitric oxide in the VNO epithelium that is involved in olfactory perception. Overall, since camel and buffalo are ruminant species, there are unclear differences in expressions of neuronal and non-neuronal markers in both VNOs. Furthermore, we suggest SYP and GFAP as markers for receptor cells and ensheathing cells of nerves of the VNO respectively.

EMAM, M. A.; EL-SHAFEY, A. A. \& KASSAB, A. A Expresión de marcadores neuronales y no neuronales en los órganos vomeronasales del camello jorobado Camelus dromedarius) y el búfalo egipcio de agua (Bubalus bubalis). Int. J. Morphol., 34(4):12071210, 2016.

RESUMEN: En este estudio fueron examinados 14 órganos vomeronasales (OVN) de machos adultos de camellos de una joroba (Camelus dromedarius) y búfalos egipcios de agua (Bubalus bubalis) ( $\mathrm{n}=7$ / cada uno) por inmunohistoquímica con marcadores neuronales, sinaptofisina (SIP) y proteína ácida fibrilar glial (PAFG), para identificar la distribución vomeronasal (VN) del receptor de células y fibras nerviosas, además de dilucidar la existencia de elementos no neuronales a través de S-100 y óxido nítrico sintasa endotelial (ONSe). En ambos animales, el OVN se encuentra alineado en sentido medial con el epitelio sensorial (olfato) y lateralmente con el epitelio no sensorial (respiratorio). En el estudio inmunohistoquímico, ambos animales mostraron marcadores inmunológicos solamente en las células receptoras del epitelio sensorial VN, mientras que la proteína ácida fibrilar glial marcaba las fibras nerviosas de OVN. Tanto el S-100 como la óxido nítrico sintasa endotelial, marcaron elementos no neuronales del OVN, las células de revestimiento del epitelio sensorial y las glándulas VN. En relación a estas observaciones, se postula que los OVN de ambos animales contienen células que expresan varios marcadores neuronales y no neuronales. SIP y la PAFG se sugieren como marcadores para células receptoras y las células gliales de nervios del OVN, respectivamente. Sin embargo, debido a que son especies de rumiantes, no existen diferencias claras que se puedan detectar en las expresiones de los marcadores neuronales y no neuronales en el OVN de camello y búfalo.

PALABRAS CLAVE: Órgano vomeronasal; Camello; Búfalo; Inmunohistoquímica. 


\section{REFERENCES}

Abass, Th. A.; Al-Mayahi, M. S. \& Al-Hussany, B. F. Anatomical and histological investigate of vomeronasal organ (VNO) in Iraqi sheep Alawasi. Kufa J. Vet. Med. Sci., 3(1):98-112, 2012.

Abbasi, M. The vomeronasal organ in buffalo. Ital. J. Anim. Sci., 6(Suppl. 2):991-4, 2007.

Ardalani, G. H.; Sadrkhanlou, R. A. \& Abbasi, M. Anatomy and histology of the vomeronasal organ in buffalo. J. Vet. Fac. Tehran Univ., 54(4):35-9, 2000.

Eisthen, H. L. Phylogeny of the vomeronasal system and of receptor cell types in the olfactory and vomeronasal epithelia of vertebrates. Microsc. Res. Tech., 23(1):1-21, 1992.

Endo, D.; Yamamoto, Y.; Yamaguchi-Yamada, M.; Nakamuta, N. \& Taniguchi, K. Localization of eNOS in the olfactory epithelium of the rat. J. Vet. Med. Sci., 73(4):423-30, 2011.

Eng, L. F. Glial fibrillary acidic protein (GFAP): the major protein of glial intermediate filaments in differentiated astrocytes. $J$. Neuroimmunol., 8(4-6):203-14, 1985.

Halpern, M. \& Martínez-Marcos, A. Structure and function of the vomeronasal system: an update. Prog. Neurobiol., 70(3):245318, 2003.

Ibrahim, D.; Abdel-Maksoud, F.; Taniguchi, K.; Yamamoto, Y.; Taniguchi, K. \& Nakamuta, N. Immunohistochemical studies for the neuronal elements in the vomeronasal organ of the onehumped camel. J. Vet. Med. Sci., 77(2):241-5, 2015.

Kahn, H. J.; Marks, A.; Thom, H. \& Baumal, R. Role of antibody to S100 protein in diagnostic pathology. Am. J. Clin. Pathol., 79(3):341-7, 1983.

Karimi, H.; Ardalani, G.; Abbasi, M.; Larijani, S. D. \& Shirmohammadi, F. The anatomy and histology of vomeronasal organ (VNO) of male Iranian helical horn goat (Capra persica). J. Anim. Vet. Adv., 6(11):1291-5, 2007.

Karimi, H.; Mansoori Ale Hashem, R.; Ardalani, G.; Sadrkhanloo, R. \& Hayatgheibi, H. Structure of vomeronasal organ (Jacobson organ) in male Camelus Domesticus Var. dromedaris persica. Anat. Histol. Embryol., 43(6):423-8, 2014.

Keverne, E. B. Importance of olfactory and vomeronasal systems for male sexual function. Physiol. Behav., 83(2):177-87, 2004.

Kim, M. K.; Park, J. H.; Kwon, B. S.; Joo, K. M.; Pyo, J. S.; Cheon, Y. H.; Baik, T. K.; Cha, C. I.; Cho, S. S.; Nam, S. Y. \& Lee, B. L. Glial fibrillary acidic protein is expressed in the aged rat olfactory epithelium. Acta Otolaryngol., 125(8):883-7, 2005.

Kimoto, H.; Haga, S.; Sato, K. \& Touhara, K. Sex-specific peptides from exocrine glands stimulate mouse vomeronasal sensory neurons. Nature, 437(7060):898-901, 2005.
Menco, B. P.; Carr, V. M.; Ezeh, P. I.; Liman, E. R. \& Yankova, M. P. Ultrastructural localization of G-proteins and the channel protein TRP2 to microvilli of rat vomeronasal receptor cells. J. Comp. Neurol., 438(4):468-89, 2001.

Nunez Chichet, M. E.; Genovese, P. \& Bielli, A. Androgen receptor distribution, PAS and Alcyan Blue reaction in the vomeronasal organ and the nasal septum mucosa of the developing male rat. Int. J. Morphol., 25(3):579-85, 2007.

Rio, C.; Dikkes, P.; Liberman, M. C. \& Corfas, G. Glial fibrillary acidic protein expression and promoter activity in the inner ear of developing and adult mice. J. Comp. Neurol., 442(2):156-62, 2002.

Smith, T. W.; Nikulasson, S.; De Girolami, U. \& De Gennaro, L. J. Immunohistochemistry of synapsin I and synaptophysin in human nervous system and neuroendocrine tumors. Applications in diagnostic neuro-oncology. Clin. Neuropathol., 12(6):335-42, 1993.

Smithson, L. J. \& Kawaja, M. D. A comparative examination of biomarkers for olfactory ensheathing cells in cats and guinea pigs. Brain Res., 1284:41-53, 2009.

Wang, R.; Jiang, S. \& Gu, R. Immunohistochemical study of the olfactory mucosa and vomeronasal organ in rat, guinea pig and human fetus. Zhonghua Er Bi Yan Hou Ke Za Zhi, 29(1):23-6, 1994.

Witt, M.; Georgiewa, B.; Knecht, M. \& Hummel, T. On the chemosensory nature of the vomeronasal epithelium in adult humans. Histochem. Cell Biol., 117(6):493-509, 2002.

Yamamoto, Y.; Henrich, M.; Snipes, R. L. \& Kummer, W. Altered production of nitric oxide and reactive oxygen species in rat nodose ganglion neurons during acute hypoxia. Brain Res., 961(1):1-9, 2003.

Zufall, F.; Kelliher, K. R. \& Leinders-Zufall, T. Pheromone detection by mammalian vomeronasal neurons. Microsc. Res. Tech., 58(3):251-60, 2002.

\section{Correspondence to:}

Dr. Mahmoud Abdelghaffar Emam

Department of Histology and Cytology

Faculty of Veterinary Medicine

Benha University

Banha 13736

EGYPT

Email: mahmoud.hussein@fvtm.bu.edu.eg

Received:17-03-2016

Accepted:10-08-2016 